\title{
Sığınmacı Çocuklar Konusunda Anne-Babaların Görüşleri
}

\section{The View of Parents About Asylum Seeker Children}

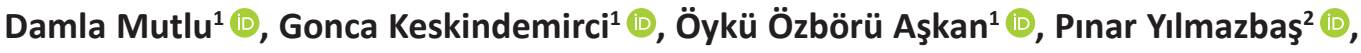

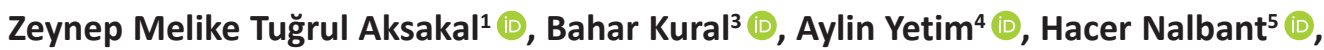 \\ Emine Gülbin Gökçay ${ }^{1}$ [D
}

\begin{abstract}
${ }^{1}$ Istanbul Üniversitesi, İstanbul Tıp Fakültesi, Çocuk Sağlığı ve Hastalıkları Anabilim Dalı, Sosyal Pediatri Bilim Dalı, İstanbul, Türkiye ${ }^{2}$ T.C. Sağlık Bakanlığı İstanbul Prof. Dr. Cemil Taşcıoğlu Şehir Hastanesi, Çocuk Sağıı̆ı ve Hastalıkları Bölümü, İstanbul, Türkiye ${ }^{3}$ T.C. Sağlık Bakanlığı İstanbul Bakırköy Dr. Sadi Konuk Eğitim Araştırma Hastanesi, Çocuk Sağlığı ve Hastalıkları Bölümü, İstanbul,Türkiye ${ }^{4}$ isstanbul Üniversitesi, İstanbul Tıp Fakültesi, Çocuk Sağlı̆̆ı ve Hastalıkları Anabilim Dalı, Ergen Sağı̆̆ı Bilim Dalı, İstanbul, Türkiye ${ }^{5}$ Istanbul Üniversitesi, İstanbul Tıp Fakültesi, Tıp Eğitimi Anabilim Dalı, İstanbul, Türkiye
\end{abstract}

ORCID ID: D.M. 0000-0001-5707-0438; G.K. 0000-0003-1797-2802; Ö.Ö.A. 0000-0002-4139-5497; P.Y. 0000-0002-1283-1712; Z.M.T.A. 0000-0001-5394-1566; B.K. 0000-0001-9528-1009; A.Y. 0000-0002-4059-1760; H.N. 0000-0002 -4246 -8547; E.G.G. 0000-0003-1042-0407

Citation/Attf: Mutlu D, Keskindemirci G, Askan OO, Yilmazbas P, Aksakal ZMT, Kural B, et al. Sığınmacı çocuklar konusunda anne-babaların görüşleri. Çocuk Dergisi - Journal of Child 2021;21(2):191-197. https://doi.org/10.26650/jchild.2021.776762

Öz

Amaç: Çalışmada ebeveynlerin sığınmacı çocuklar konusundaki görüşünü ve sorunlara çözüm önerilerini öğrenmek amaçlanmıştır. Gereç ve Yöntem: Çalışmaya Haziran 2017-Ekim 2017 tarihleri arasında İstanbul'daki beş ayrı çocuk sağlığı izlem polikliniğine başvuran, gönüllü 231 ebeveyn dahil edilmiştir. Ebeveynlere demografik bilgilerin yanı sıra sığınmacı çocuklarla ilgili soruları içeren anket yüz yüze görüşme tekniği ile uygulanmıştır.

Bulgu: Çalışmamıza katılan ebeveynlerin \%80'i (n=183) sığınmacı çocukların sağlık hizmetinden faydalanabildiğini, \%67'si ( $n=151)$ ise eğitim hizmetinden faydalanabildiğini düşünmektedir. Sığınmacı çocukların katılımcılara göre başlıca sorunlarını; barınma (\%34,2), eğitim $(\% 22,6)$, maddi problemler ve çocuk işçiliği $(\% 13,7)$, lisan $(\% 11,6)$ ve sağlık $(\% 6,3)$ sorunları oluşturmaktadır. Sığınmacı ailelerin ve çocukların eğitimi $(\% 32,9)$, ülkelerine geri dönmeleri (\%25), çocukların devlet korumasına alınması $(\% 15,1)$ var olduğu düşünülen sorunlara getirilen başlıca çözüm önerileridir.

Sonuç: Sığınmacı çocukların temel hakları arasında sayılan ve göç edilen topluma uyumda önemli yere sahip olan eğitim, barınma ve sağlık başlıkları çalışmaya katılan aileler tarafından hem sorunlar arasında sayılmış hem de çözüm önerileri arasında yer almıştır. Ebeveynlerin sığınmacı çocukların sağlık ve eğitim hizmetinden faydalandığını düşündüğü halde bu başlıkları sorun olarak da bildirmesi verilen hizmetlerin etkin olmadığının düşünüldüğüne dair bir bulgu olarak değerlendirilmiştir.

Anahtar Kelimeler: Çocuk, Çocuk hakları, Mülteci, Sığınmacı
ABSTRACT

Aim: The aim of the study was to learn the views of parents within the community on asylum seeker children and to learn their solution proposals for their problems.

Materials and Methods: Our study was conducted with 231 voluntary parents who were admitted to five different child health clinics between June and October 2017. The survey, which consists of demographics information and questions about asylum seeker children were asked to the parents in a face to face interview.

Results: Eighty percentage of participants $(n=183)$ thought that asylum seeker children had the opportunity to use the health service. Sixty seven percentage $(n=151)$ thought that they had the opportunity to be involved in the educational system. According to the participants, the biggest problems for asylum seeker children are; housing (34.2\%), education (22.6\%), poverty and child labour (13.7\%), language related problems (11.6\%) and health issues (6.3\%). Their main solution proposals were; the education of parents and children (32.9\%), their deportation back to their country $(25 \%)$ and to have the asylum seeker children under government protection (15.1\%).

Conclusion: Health, education and housing were thought to be the biggest problems for asylum seeker children and the solution proposals mostly took place under those topics according to participant parents. They also thought that asylum seeker children had the opportunity to use health and education services. The efficiency of those services was questioned by parents because they also stated that asylum seeker children had problems in accessing those services.

Keywords: Asylum seeker, Child, Child rights, Immigrant

Corresponding Author/Sorumlu Yazar: Damla Mutlu E-mail: damlaka@yahoo.com

Başvuru/Submitted: 04.08.2020 • Revizyon Talebi/Revision Requested: 03.11.2020 • Son Revizyon/Last Revision Received: 24.11.2020 • Kabul/Accepted: 13.07.2021 


\section{Gíiş}

Cenevre 1951 Sözleşmesine göre; ülkesinde meydana gelen savaş, çatışma, saldırı, doğal afet sebebiyle yaşamından endişe duyan ya da ırk, din, sosyal konum, siyasal düşünce ya da ulusal kimliği nedeniyle ayrımcılığa uğradığını düşünerek kendi ülkesine olan güvenini yitiren, bu sebeplerle ülkesini terk edip başka bir ülkeye sığınarak uluslararası koruma talebinde bulunan kişilere sığınmacı denir. Sığınmacı olan kişinin korunma talebi sığındıkları ülke tarafindan kabul görürse, bu kişi mülteci olarak adlandırılır (1). Dünya çapında, 2019 yılında, yaklaşık 26 milyonu mülteci, 4,2 milyonu sığınmacı olmak üzere toplamda 79,5 milyon kişinin farklı sebeplerden dolayı yaşadıkları yerleri terk etmeye zorlandığı bildirilmiştir (2).

Türkiye 1980'lerden itibaren Bulgaristan'dan, Irak ve İran'dan, Asya Ülkeleri ve Kafkasya'dan ve dağılan Yugoslavya'dan yoğun göç almıştır. Son dönemde ise Suriye'deki kriz sebebiyle milyonlarca Suriyeliye sığınma hakkı verilmiştir (3). Suriye'de 2011 yılında baş gösteren kriz sonrasında Türkiye Cumhuriyeti (T.C.), Suriyeli sığınmacılara açık kapı politikası uygulamış ve sığınmacıların 'geçici koruma' statüsünde ülkeye girişleri sağlanmıştır. Türkiye'deki Suriyeli sığınmacı sayısı 2017 yılında yaklaşık 3,4 milyon, 2020 yılında ise güncel verilere göre 3,6 milyondur. Türkiye dünyada en fazla sığınmacı barındıran ülkedir. Sığınmacıların 1,7 milyonu 0-18 yaş arasındadır $(4,5)$. Ebeveynleri veya refakatçileri olmadan tek başına göç eden çocukların kayıt altına alınması güç olduğundan Türkiye'deki çocuk sığınmacı sayısının daha fazla olduğu düşünülmektedir (6). Sığınmacı ve mülteci çocukların arasında yer alan bebekler ve küçük çocuklar, özel sağlık gereksinimi olan çocuklar ve engelli çocuklar, kaybolmuş veya yolda kalmış çocuklar ve 14-17 yaş arası refakatsiz adolesanlar özellikle hassas olan ve yakından izlenmesi gereken gruplardır (7).

Çocuk Hakları Sözleşmesi'nin 22. Maddesi sı̆̆ınmacı ve mülteci çocukların özel olarak korunması ve desteklenmesi gerektiğini vurgular. Bütün çocuklar gibi sığınmacı çocukların da ayrımcılığa uğramamaları (2. madde), her koşulda yararlarının düşünülmesi (3. madde), yaşama ve gelişme haklarının korunması (6. madde), her türlü şiddet, istismar ve ihmale karşı korunmaları (19. ve 34. maddeler), sağlık ve eğitimden koşulsuz faydalanmaları (24. ve 28. maddeler) ve sosyal güvenlikten yararlanmaları (26. madde) gerekmektedir (8).

Sığınmacıların hakları Yabancılar ve Uluslararası Koruma Kanunu ile tanımlanmış olup devlet tarafindan sunulan yardımlar bu haklar temelinde yapılmaktadır (9). Türkiye'de sığınmacılara yönelik hizmetler, özellikle Afet ve Acil Durum Yönetimi, Kızılay ve yerel belediyeler tarafindan gerçekleştirilmektedir. Bölgesel Sivil Toplum Kuruluşları yaşanan sorunlara yönelik çözüm önerileri ve eylem planlarıyla önemli bir rol üstlenmektedir (10).

Türkiye, Mültecilerin Hukuki Durumuna İlişkin Cenevre Sözleşmesi'ne (1951) ve 1967 yılı Ek Protokol'üne coğrafi çekince nedeniyle taraf olmuştur. Bu çekince nedeniyle Avrupa dışı ülkelerden gelenler mültecilik statüsü dışında tutulmaktadır (3). Türkiye'deki Suriyeli sığınmacılar da mültecilik statüsüne eşit haklara sahip değildir. Her ne kadar ülke topraklarına kabul, geri gönderilmeme, temel ve acil ihtiyaçların karşılanması gibi haklara sahip olsalar da eğitim, sağlık ve istihdam konusundaki haklarının iyileştirilmesi gerekmektedir (11). Aynı zamanda Türkiye'ye göç eden Suriyeli sığınmacılar sürecin başından itibaren dil, din, mezhep, ırk gibi sebepler yüzünden topluma uyum konusunda zorluk yaşamışlardır (12). Toplumun sığınmacılara karşı ön yargılı olması sığınmacılar açısından en önemli sorunlardan biri olarak görülmektedir. Bu tutum aynı zamanda; yerel halk ile sığınmacılar arasında etkin iletişimin kurulmasını engellemekte, uyum problemini daha da arttirmaktadır (13).

Bu çalışma anne ve babaların sığınmacı çocuklar konusundaki görüşlerini ve sorunlara çözüm önerilerini öğrenmek amacıyla yapılmıştır.

\section{GEREÇ VE YÖNTEM}

Çalışma Haziran-Ekim 2017 tarihleri arasında İstanbul'da bulunan Koç Üniversitesi Hastanesi, İstanbul Üniversitesi İstanbul Tıp Fakültesi, T.C. Sağlık Bakanlığı İstanbul Bakırköy Dr.Sadi Konuk Eğitim Araştırma Hastanesi, T.C. Sağlık Bakanlığı İstanbul Prof. Dr. Cemil Taşcıoğlu Şehir Hastanesi, T.C. Sağlık Bakanlığı İstanbul Medeniyet Üniversitesi Göztepe Eğitim ve Araştırma Hastanesi, Okan Üniversitesi Hastanesi Çocuk Sağlığı İzlem polikliniklerine başvuran ve yazılı bilgilendirilmiş onam formunu okuyup imzalayarak gönüllü olarak katılmayı kabul eden 231 ebeveyn ile gerçekleştirilmiştir. Gönüllü onam formu dolduran ebeveynlerden, anketin demografik özellikleri sorgulayan kısmını doldurmayı reddeden kişiler çalışmaya dahil edilmemiştir.

Katılımcıların mülteci çocuklar konusunda görüş ve önerilerini sorgulayan bir anket yüz yüze görüşme tekniği kullanılarak uygulanmıştır. Ankette ebeveynlerin yaşı, eğitim durumu, mesleği, ailedeki kişi ve çocuk sayısı gibi demografik bilgilerin yanı sıra sığınmacı çocuklarla karşılaşma sıklıkları, nerde karşılaşttkları, sağlık ve eğitim hizmetinden sığınmacı çocukların faydalanması hakkındaki düşünceleri, sığınmacı çocuklarla yaşanan olumlu veya olumsuz deneyimleri, lisanın problem olup olmadığı, sığınmacı çocuklar için en önemli sorunların ne olduğu ve bu sorunlarla ilgili çözüm önerileri açık uçlu sorular ile sorgulanmıştır. Çalışma için İstanbul Üniversitesi İstanbul Tıp Fakültesi Etik Kurulu'ndan onay alınmıştır.

İstatistiksel analizler için SPSS 21.0 programı (IBM SPSS Statisitcs 21. version) kullanıldı. Çalışma verileri tanımlayıcı istatistiksel metotlar (ortalama, standart sapma, medyan, frekans, yüzde, minimum, maksimum) kullanılarak değerlendirilmiştir.

\section{BULGULAR}

Çalışmaya katılmaya onay veren 304 ebeveynden, anketin demografik özellikleri sorgulayan kısmını doldurmayı reddeden 73'ü çalışmaya dahil edilmemiştir ve 231 ebeveyn çalışmanın evrenini oluşturmaktadır. Ebeveynlerin yaş ortalaması 35,5 $\pm 7,8$ idi ve \%80'i ( $n=183$ ) kadın cinsiyetindeydi. Katılımcıların \%32'si $(n=74)$ ilköğretim, \%25'i ( $n=57)$ lise, \%43'ü ( $n=99)$ ise üniversite 


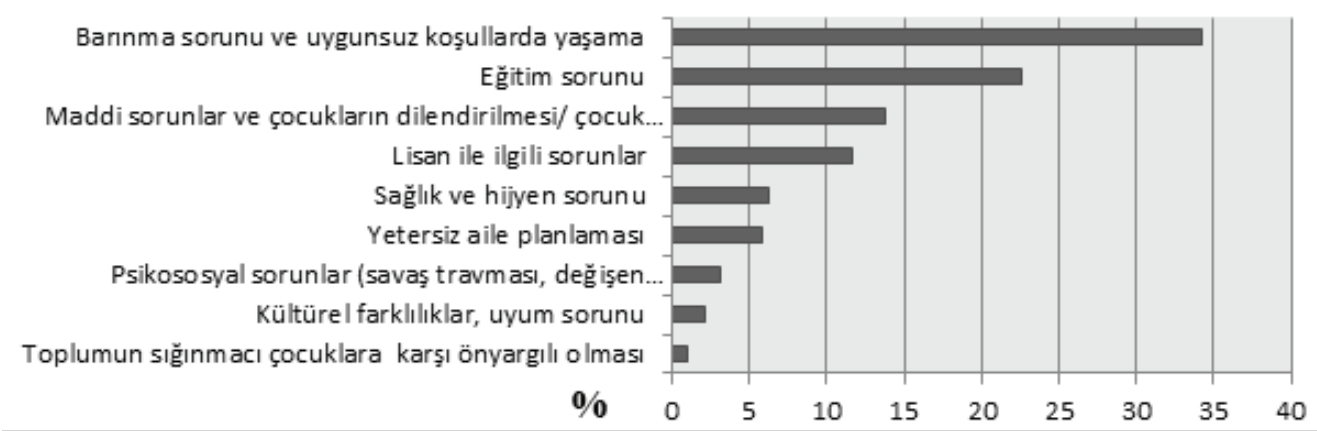

Şekil 1: Katılımcı ebeveynlerin görüşlerine göre sığınmacı çocukların sorunları.

mezunu olmakla birlikte anketin doldurulduğu dönemde çalışma oranı \%62,5 ( $n=140)$ olarak bulunmuştur. Ailedeki kişi sayısı ortalaması $4 \pm 1$ ailedeki çocuk sayısı ortalaması $2 \pm 1$ idi.

Ebeveynlerin \%96'sı (n=221) gündelik hayatta sığınmacı çocuklarla karşılaştğını ifade etmiştir. Gündelik hayatta sığınmacı çocuklarla karşılaşan grubun \%72'si ( $n=160)$ her gün, $\% 22$ 'si $(n=49)$ haftada birkaç gün, \%5'i ( $n=12)$ ise ayda birkaç gün karşılaşthğını belirtti. Sığınmacı çocuklarla en sık karşılaşma yeri $\% 80(n=177)$ ile sokak ve $\% 32(n=67)$ ile hastane olduğu belirlenmiştir.

Sığınmacı çocuklarla bir deneyim yaşamış olan ebeveyn sıklığı $\% 47(n=109)$ iken bu deneyimlerin \%36'sının ( $n=39$ ) olumlu olduğu belirtilmiştir. Bu deneyimleri sırasında \%88'i $(n=97)$ orta ve ileri düzeyde dil problemi yaşadığını ifade etmiştir.

Katılımcıların \%.80'i (n=183) sığınmacı çocukların sağlık hizmetinden faydalanabildiğini, \%16'sı ( $n=36)$ faydalanamadığını düşünmekte olup $\% 5^{\prime} i(n=11)$ ise bu konuda bilgisi olmadığını ifade etmiştir. Sığınmacı çocukların eğitim hizmetinden faydalanabildiğini düşünen ebeveynlerin oranı \%67 ( $n=151)$ iken, \%26'sı ( $n=60)$ faydalanamadığını düşünmektedir. Katılımcıların \%7'si ( $n=15)$ ise bilgisi olmadığını belirtmiştir.

Çalışmaya dahil edilen 231 ebeveynden 29'u sığınmacılar ile ilgili herhangi bir sorun belirtmediği, 12'si konu ile ilişkisiz yanıt verdiği için sorunlara ilişkin 190 yanıt değerlendirilmiştir. Ebeveynlerin ifadelerine göre sorunlar Şekil 1'de gösterilmiştir.

Sığınmacı çocukların sorunlarına yönelik çözüm önerileri sorulduğunda katılımcıların \%65,8'i $(n=152)$ öneride bulunmuştur. Bu öneriler değerlendirildiğinde en sık önerilen çözümler aile ve çocukların eğitimi $(\% 32,9)$, ülkelerindeki sorunlar çözüldükten sonra geri dönmeleri (\%25) ve çocukların devlet korumasına alınması $(\% 15,1)$ şeklinde olmuştur. Ebeveyn görüşlerinde belirtilen sığınmacı çocukların sorunlarına yönelik öneriler Tablo 1'de gösterilmiştir.

\section{TARTIŞMA}

Ebeveynlerin sığınmacı çocukların sorunları ile ilgili algısını ve bu sorunlara getirilen çözüm önerilerini saptamayı amaçlayan çalışmamız bu konuda yapılan çok merkezli bir çalışma olması nedeniyle önemlidir. Çalışmamızda ebeveynlerin sığınmacı sorunları olarak belirttiği ana sorunlar; barınma, eğitim, istihdam ve sağlık alanında olduğu görülmüştür. Göç eden
Tablo 1: Sığınmacı çocukların sorunlarına yönelik çözüm önerileri.

\begin{tabular}{|c|c|}
\hline Sorunlar & Öneriler \\
\hline $\begin{array}{l}\text { Barınma sorunu } \\
\text { ve uygunsuz } \\
\text { koşullarda yaşama }\end{array}$ & $\begin{array}{l}\text { - Ayrı barınma alanları sağlanması } \\
\text { - Ailelere iş imkanı ve konut sağlanması } \\
\text { - Çocukların devlet korumasına girmesi } \\
\text { - Savaşın sonlanması ve ülkelerine geri } \\
\text { dönmeleri }\end{array}$ \\
\hline Eğitim sorunu & $\begin{array}{l}\text { - Çocuk işçi ya da dilenen çocukların devlet } \\
\text { korumasına girmesi } \\
\text { • Çocukların eğitimin desteklenmesi } \\
\text { - Devlet kontrolünde eğitim sağlanması } \\
\text { • Kayıt altına alınmaları }\end{array}$ \\
\hline $\begin{array}{l}\text { Maddi sorunlar ve } \\
\text { çocukların } \\
\text { dilendirilmesi/ } \\
\text { çocuk işçiler }\end{array}$ & $\begin{array}{c}\text { - Ebeveyne istihdam, çocukların devlet } \\
\text { koruması altında olması } \\
\text { • İstismar/ihmal açısından yakın takip edilerek, } \\
\text { güvenli ortam sağlanması } \\
\text { • Çocukların eğitimin desteklenmesi } \\
\text { • Eğitim, sağlık, ihmal/istismardan korunma } \\
\text { haklarının yeterince sağlanması } \\
\text { • Kayıt altına alınmaları }\end{array}$ \\
\hline $\begin{array}{l}\text { Sağlık ve hijyen } \\
\text { sorunu, yetersiz } \\
\text { aile planlaması }\end{array}$ & $\begin{array}{c}\text { • Ülke girişlerinde sağlık kontrolü } \\
\text { • Sağlık hizmetinden faydalanabilmesi } \\
\text { • Aile planlaması } \\
\text { • Ebeveynlik becerilerinin geliştirilmesi için } \\
\text { eğitim } \\
\text { • Kayıt altına alınmaları }\end{array}$ \\
\hline $\begin{array}{l}\text { Psikososyal } \\
\text { sorunlar (savaş } \\
\text { travması, değişen } \\
\text { yaşam koşulları) }\end{array}$ & $\begin{array}{l}\text { - Eşit sosyal haklardan faydalanılması } \\
\text { - Devlet korumasına girmesi } \\
\text { - Psikolojik destek verilmesi }\end{array}$ \\
\hline $\begin{array}{l}\text { Kültürel } \\
\text { farklılıklar, lisan ile } \\
\text { ilgili sorunlar ve } \\
\text { uyum sorunu }\end{array}$ & $\begin{array}{l}\text { - Planlı entegrasyon (topluma uyum) sağlanmal } \\
\text { • Dil eğitimi verilmesi } \\
\text { • Aile eğitimi verilmesi } \\
\text { • Eğitimin desteklenmesi }\end{array}$ \\
\hline $\begin{array}{l}\text { Sığınmacı } \\
\text { çocuklara karşı } \\
\text { önyargı }\end{array}$ & $\begin{array}{l}\text { - Eğitim, sağlık ve sosyal haklardan eşit } \\
\text { faydalanılması, ayrımcılık yapılmaması }\end{array}$ \\
\hline
\end{tabular}

toplulukların, göç ettikleri topluma uyumlarını belirleyen ana öğeler ile örtüşen bu sorunların literatür ile uyumlu olduğu görülmüştür (14).

Çalışmamızda sığınmacı çocuklara yönelik belirtilen en önemli sorunlardan biri barınma $(\% 34,2)$ olarak saptanmıştır. Suriyeli sığınmacıların barınma ihtiyaçları için başlangıçta Suriye 
sınırına yakın 10 ilde 16 çadırkent kurulmuş fakat sığınmacılar farklı illerde ve belirlenen kampların dışında yaşamayı tercih etmiştir (15). Göç İdaresi Genel Müdürlüğü'nün 2020 istatistik verilerine göre sığınmacıların en fazla yaşamayı tercih ettiği iller; İstanbul, Şanlıurfa, Gaziantep ve Hatay'dır. Aynı verilere göre Türkiye'de aktif olan yedi geçici barınma merkezinde 62,580 Suriyeli sığınmacı ikamet etmekte; geri kalan yaklaşık 3,532,000 kayıtlı sığınmacı kamp dışında yaşamaktadır (5). Çalışmamızdaki öneriler arasında sığınmacılara kamp gibi ayrı barınma alanları sağlanması, ailelere konut sağlanması ve barınma ile ilgili sosyal hakların düzenlenmesi yer almaktadır. Göç alan yerel halkın görüşlerinin değerlendirildiği başka bir çalışmada katılımcıların \%68'i Suriyeli sığınmacıları yaşadıkları mahallelerde görmek istemediklerini ve evlerini sığınmacılara kiraya verme taraftarı olmadıklarını belirtmiş, sığınmacıların Suriye sınırına yakın bölgelerde onlara özel alanlara yerleştirilmesini önermiştir (12). Koç ve ark. sığınmacı kamplarındaki koşulların, sağlık hizmetinin ve sosyal hizmetlerin ikamet eden sığınmacılar için yeterli düzeyde olduğunu vurgulamıştır. Kamp dışı ikamet sebebi; kayıt dışı olma, kamp yaşamına uyum sağlayamama, maddi imkanların yeterliliği, kampın dolu oluşu, akrabaları ile kalma isteği olarak sınıflandırılmıştır (16). Diyarbakır'da kamp dışında yaşayan sığınmacılara neden kampı tercih etmedikleri sorulduğunda ise; hijyen problemi, ısınma problemi, yaşam alanının ve sosyal yaşamın sınırlandırılması, iş bulmada zorlanma gibi sebepler ileri sürülmüştür (17). Alptekin ve ark. Konya ilindeki kamp dışında yaşayan sığınmacıların çoğunlukla yaşam şartları bakımından elverişsiz olan, kentsel dönüşüm nedeniyle boşaltılan apartmanlara yerleştirildiğini, işhanlarındaki dairelerde yaşamak zorunda kaldıklarını, bu alanlara yüksek kiralar ödediklerini ve evden çıkarılma korkusu yaşadıklarını belirtmiştir (18). Çalışmamızda katılımcıların bir kısmı ayrı barınma alanlarını/kampları barınma sorununa çözüm olarak önermiştir fakat kamplar geçici barınma merkezleridir. Çocuk hakları sözleşmesi uyum çerçevesinde değerlendirildiğinde çocukların toplum içerisinde yer almaları ailelerin iş gücüne adil bir şekilde katılımı ile mümkün olacaktır. Çalışmamızda da ailelere konut ve iş imkânı sağlanmasının barınmaya ilişkin diğer öneriler arasında olduğu görülmüştür.

Maddi sorunlar, çocuk işçiliği ve çocukların dilendirilmesi sorununa \%13,7 katılımcı değinmiş olup, \%15,1 katılımcı çözüm önerisi olarak çocukların devlet korumasına alınmasını önermiştir. Türkiye'deki Suriyeli sığınmacıların ağırlıklı olarak yaşadıkları illerde ucuz iş gücü olması sebebiyle çocuk işçiliği artmış olup çocuklar en çok tekstil, inşaat, tarım ve hayvancılık alanında çalıştırıldığı bildirilmiştir (19). Sığınmacı çocukların çocuk iş̧̧i olmalarının engellenmesi için ekonomik sıkınt yaşayan ailelerin desteklenmesi ve iş gücüne katılımlarının sağlanmasının önemi vurgulanmıştır (20). Sığınmacıların çalışmasına sınır getiren hukuki düzenlemelerden dolayı çalışan çoğunluk kayıt dışı istihdam grubundadır (21). Yıldırımalp ve ark. çalışmasına katılan sığınmacılar sosyal güvenceden yoksun, alt gelir seviyesinde günübirlik işlerde çalıştıklarını, pis ve zor işlerde görevlendirildiklerini, uzun ve düzensiz çalışma saatlerinin olduğunu ifade etmiştir. Bu durum Suriyeli sığınmacıların çoğunun düşük eğitim seviyesine sahip olması ile ilişkilendirmiştir (22). Çalışma mevzuatında sığınmacılara dair yer alan kısıtlamaların azaltılması, sığınmacıların maaşlarının işverenler tarafindan banka yoluyla verilerek asgari ücret altında maaş almalarının engellenmesi, ihtiyaç duyulan mesleklere yönelik eğitim verilmesi ve iş gücünün bu kesimlere yönlendirilmesi çözüm önerisi olarak sunulmuştur (21). Çalışmamızda ailenin ekonomik iş gücüne katılımı çözüm önerileri arasında yer alsa da ağırlıklı olarak çocukların devlet korumasına alınması önerilmiştir. Bununla birlikte çocuk hakları sözleşmesine göre her çocuğun ailesi ile birlikte yaşamaya hakkı vardır. Devlet de aileyi sorumluluklarını yerine getirip getirmediği ile ilgili denetlemekle yükümlüdür (8). Göç sonrasında sığınmacı küçük kızların dini nikâh ile evlendirilmesinin yaygınlaştı̆̆ ve evlenme yaşının 11-12'ye kadar düştüğü literatürde yer almaktadır (23). İstismar ve ihmal açısından çocukların yakın takip edilmeleri ve çocuk güvenliği için gerekli olan sosyal hakların iyileştirilmesi katılımcılar tarafindan sunulan çözüm önerileri arasında yer almaktadır.

Ekonomik Kalkınma ve İşbirliği Örgütü (OECD) 2016 Raporunda; ülkede kalma ihtimali yüksek olan sığınmacıların becerilerine yönelik istihdam edilmesi ve uyum için gerekli olan eğitimleri almalarının önemi vurgulanmıştır. Eğitim alanındaki desteği geciken sığınmacıların uyumunun da daha uzun süreceği özellikle belirtilmiştir (24). Çalışmamıza katılanların kültürel farklılıklar, dil problemi ve uyum problemine yönelik başlıca çözüm önerileri benzer şekilde olup; uyum için devletin çaba göstermesi, uyuma yönelik sığınmacılara eğitim verilmesi, sığınmacı ailelere ve çocuklara dil eğitimi verilmesi yönündedir. Çakır'ın çalışmasında Suriyeli kadınlar kendilerini ifade edemediklerini ve söyleneni anlayamadıklarını belirtip, iletişimin en önemli sorun olduğunu vurgulamışlardır (25). Karasu'nun çalışmasında ise katılan sığınmacıların \%81,6'sı dil bilmemeyi, \%33,9'u ise sosyal ve kültürel uyumsuzluğu yaşadıkları sorunlar arasında saymıştır (26). Yıldırımalp'in çalışmasına katılan sığınmacılar da dil yetersizliği sebebiyle toplumdan izole yaşadıklarını ifade etmiştir (22). Göç edilen topluma uyum için lisanın önemi hem çalışmamızda hem de Suriyeli sığınmacıların görüşlerini içeren çalışmalarda yüksek oranda vurgulanmıştır. Devlet kurumlarının, belediyelerin ve Sivil Toplum Kuruluşları'nın bu alanda çalışmalar yaptığı bilinmektedir (27).

Çocuk Hakları Sözleşmesi'nde belirtilen eğitim hakkı nedeniyle tüm sığınmacı çocuklar gelişimsel ihtiyaçlarına uygun bir şekilde eğitim sistemi içerisine dahil edilmelidir. Çalışmamıza katılanların \%67'si sığınmacı çocukların eğitim hakkından faydalandığını düşündüğü halde sığınmacılarla ilgili sorunların arasında eğitim sorunu ikinci sırada $(\% 22,6)$ yer almıştır. Sığınmacı çocukların geleceğine yönelik çözüm önerilerinin ilk sırasında da $(\% 32,9)$ eğitimin olduğu görülmüştür. Türkiye İnsani Durum Raporu'na göre 2018 yılında çoğunluğunu Suriyelilerin oluşturduğu yaklaşık 645,000 sığınmacı çocuk devlet okullarında ve Suriyeli gönüllü öğretmenlerin de görevlendirildiği Geçici Eğitim Merkezleri'nde (GEM) eğitim görmüş olup 47,000 çocuk ise erken çocukluk dönemi eğitimine dahil edilmiştir. Aynı raporda 400,000 Suriyeli çocuğun eğitim hakkının farkında olmaması, lisan problemi, sosyoekonomik durum veya ilköğretim sonrası terk gibi sebeplerle eğitim 
sisteminde yer almadığı belirtilmiştir. 2019 yılı raporunda eğitim sisteminde yer alamayan çocuk sayısı aynı kalmıştı $(28,29)$. Çocukların eğitim sistemine dahil edilmesi ve desteklenmesi, Türkçe dilini öğrenmelerine yönelik eğitim verilmesi ve eğitimin devlet kontrolünde olması katılımcıların eğitim alanında sunduğu çözüm önerileri arasında yer almaktaydı. Okul öncesi eğitim kurumlarındaki öğretmenlerle yapılan bir çalışmada sığınmacı çocukların dil problemi nedeniyle akranlarıyla ve öğretmenleriyle iletişim kurmakta zorlandıkları ve uyum konusunda zorluk yaşadıkları ifade edilmiştir (30). Yapıcı'nın çalışmasına katılan GEM'de çocuğunu okutan sığınmacı aileler, devlet okullarında çocuklarının akran zorbalığına ve öğretmen tarafindan ayrımcılığa uğrayacağı ile ilgili endişeleri olduğunu ve anadillerinde eğitim istediklerini ifade etmiştir (31). Kaya'nın çalışmasında ise sığınmacı ailelerin GEM'leri tercih etmesindeki sebepler; çocukların anadilleri olan Arapçayı unutmamaları, kültürel özelliklerini yitirmemeleri olarak ifade edilmiştir (32). Sığınmacılara kendi anadillerinde eğitim imkânı sunan Geçici Eğitim Merkezleri yakın dönemde kapatılıp çocuklar devlet okullarına yönlendirilmiştir. Eğitim sistemine dahil edilemeyen çocuk sayısı düşünüldüğünde, çalışmamıza katılan ailelerin belirttiği gibi eğitimin sığınmacılar için hala bir sorun olduğu görülmüştür. Dahil olan çocukların yaşadığı dil problemi, akran zorbalığı ve ayrımcılık çözülmesi gereken problemler arasındadır. Türkçe dil eğitiminin etkin bir şekilde verilmesinin ardından kademeli geçişin sağlanması, öğretmenlerin sığınmacı çocuklara yaklaşıma yönelik aldıkları eğitimlerin daha etkin hale getirilmesi çözüm önerileri arasında sayılabilir (33).

Ülkemizde 2003 yılı itibari ile Aile, Çalışma ve Sosyal Hizmetler Bakanlığı ve Milli Eğitim Bakanlığı ortaklığında, nüfusun en yoksul kesiminde yer alan, maddi imkansızlıklar nedeniyle çocuklarını okula gönderemeyen ailelere, çocuklarının okula devam etmeleri şartıyla Şartı Eğitim Yardımı yapılmaktadır (34). Ulusal düzeyde olan bu yardım 2017 yılında Birleşmiş Milletler Çocuklara Yardım Fonu (UNICEF) ve Avrupa Birliği'nin desteğiyle Suriyeli ve diğer mülteci aileleri kapsayacak şekilde genişletilmiştir. Bu sayede en kırılgan durumdaki mülteci çocuklar tespit edilmiş ve gerektiğinde çocuk koruma hizmetlerine yönlendirilmiştir (35).

Göç sürecinde yaşananlar çocukların fiziksel, ruhsal ve sosyal gelişimlerini kötü yönde etkilemektedir. Mülteci ve sığınmacı çocuklar; akut ve kronik hastalıklar, bulaşıcı hastalıklar, yetersiz beslenme (malnutrisyon), global/ izole gelişim gerilikleri, kazalar, post travmatik stres bozukluğu, depresyon, kaygı bozukluğu, uyku ve yeme bozukluğu, psikosomatik bozukluklar, agresyon, DEHB (dikkat eksikliği hiperaktivite bozukluğu), davranışsal problemler (bağımlılık, suça yönelme, şiddet uygulama) açısından riskli bir gruptur (36-38). Çalışmamıza katılanların sığınmacı çocukların fiziksel sağlık sorunlarına yönelik başlıca çözüm önerileri; ülke girişlerinde sağlık kontrolleri yapılması, sağlık hizmetine daha kapsamlı ve daha rahat erişimlerinin olması şeklindedir. Ruhsal sağlık sorunlarına yönelik çözüm önerileri ise psikolojik destek almaları şeklindedir. Sınır geçişlerinde 'geçici koruma kimlik belgesi' alan ve kayıt altına alınan Suriyeli sığınmacılar kayıtlı oldukları illerdeki kamu sağlık kuruluşlarına doğrudan başvurabilme ve
Genel Sağlık Sigortalılar için sunulan sağlık hizmetlerinden faydalanma hakkına sahiptir. Kamp dışında yaşayan çocukların önemli bir oranı doğum sonrası kayıt altına alınmaması sebebiyle sağlık hizmetlerinden yararlanamamakta, kötü yaşam koşulları ve eksik aşılanma nedeniyle bulaşıcı hastalık riskleri yüksek olmaktadır (37). Kayıt altında olmayanlar yalnızca acil ve bulaşıcı hastalıklar durumunda kamu sağlık hizmetlerinden yararlanabilmektedir (39). Sığınmacılara yönelik koruyucu sağlık hizmetleri Toplum Sağlığı Merkezleri ve Aile Sağlığı Merkezleri tarafindan sunulmaktadır. Ülkemizdeki bağışıklama, tarama ve izlem hizmetleri geçici koruma altında olanlara aynı şekilde sunulmaktadır (40). Sığınmacıların sağıık değerlendirmelerinin sınır geçişlerinde yapıldığı ve yaşlarına ve gebelik durumlarına göre bağışıklama hizmeti verildiği bilinmektedir (41). Kayıt altına alınmayan sığınmacı gruplarda ise aşısız ve eksik aşılı çocuk oranının yüksek olduğu ve bu çocukların hem kendileri hem de toplum için bulaşıcı hastalık riskini artırdığına yönelik çalışmalar literatürde yer almaktadır (42-43). Sığınmacı nüfusunun yüksek olduğu bölgelerde hem Türk çocuklara hem de sığınmacı çocuklara çocuk felcine ve kızamığa yönelik aşı kampanyaları da düzenlenmiştir (44). Kara ve ark. çalışmasında ise sığınmacıların sağlık hizmetine ulaşamamalarının temel nedeninin dil sorunu olduğu ve bu sebeple aile hekimliklerine kayıt yaptırmak istemedikleri belirtilmiştir (45). Çalışmamıza katılanların \%80'i sığınmacı çocukların sağlık sisteminden faydalanabildiği yönünde görüş bildirmiş olup yalnızca \%6,3'ü sağlığın sığınmacı çocuklar için bir sorun teşkil ettiğini düşünmektedir. Kayıtlı olmayan sığınmacı çocukların sağlık hizmeti erişiminde zorluklar yaşadığı bilinmektedir. Fiziksel ve ruhsal hastalıklara karşı hassas bir grup oldukları bilinen bu çocuklar için sağlık başlıca problemlerden biri olarak literatürde yer almaktadır.

Çalışmamız verileri tek bir ile ait olmakla birlikte, İstanbul ili Türkiye'yi temsil edebilecek düzeyde demografik özellikler içeren bir il olması ve yüksek sayıda sığınmacı barındırması nedeniyle kısıtlılık olarak değerlendirilmemiştir.

\section{SONUÇ VE ÖNERILER}

Ebeveynlere göre sığınmacı çocuklarla ilgili sorunlar ve çözüm önerileri eğitim, barınma, istihdam ve sağlık başlıkları altında toplanmıştır. Dil eğitiminin öneminin her başlık altında vurgulandığı görülmüştür. Katılımcıların bir kısmı ayrı barınma alanlarını/kampları barınma sorununa çözüm olarak önermiştir fakat kamplar geçici barınma merkezleridir. Ailelere iş imkânı ve konut sağlanması verilen öneriler arasındadır. Katılımcılar yüksek oranda bu çocukların eğitim hakkından faydalandığını düşünmektedir ama hala eğitim sistemi dışında olan 400,000 çocuk olduğu bilinmektedir. Katılımcılar eğitimin devlet kontrolünde olmasını önermiştir fakat sığınmacıların devlet okullarında dil problemi, akran zorbalığı ve ayrımcılık gibi durumlara yönelik endişeleri bulunmaktadır. Ebeveynler sığınmacı çocukların sağlık hizmetinden de yüksek oranda faydalandığı düşünmüş ama sağlığı da çözülmesi gereken sorunlardan biri olarak belirtmişlerdir. Bu çocuklar fiziksel ve ruhsal hastalıklar açısından riskli bir gruptur ve kayıt altında olmayan kesim sağlık hizmetine erişimde zorlanmaktadır. 
Sığınmacı çocukların desteklenmesi için toplumsal farkındalığın artırılması, uyuma yönelik eğitimlerin yaygınlaştırılması ve bu alanda hem göç eden bireylerin hem de göç alan toplumun bakış açısını içeren geniş çaplı disiplinler arası çalışmaların yapılması yararlı olacaktır.

Etik Komite Onayı: Çalışma için İstanbul Üniversitesi İstanbul Tıp Fakültesi Etik Kurulu'ndan onay alınmıştrr.

Bilgilendirilmiş Onam: Katlımcılardan bilgilendirilmiş onam alınmıştır.

Hakem Değerlendirmesi: Dış bağımsız.

Yazar Katkıları: Çalışma Konsepti/Tasarım- G.G., G.K., H.N., D.M.; Veri Toplama- D.M., G.K., Ö.Ö.A., P.Y., Z.M.T.A., B.K., A.Y.Ş.; Veri Analizi/ Yorumlama- Ö.Ö.A., G.K.; Yazı Taslağı- D.M., G.K., Ö.Ö.A., P.Y., Z.M.T.A., B.K., A.Y.Ş.; İçeriğin Eleştirel İncelemesi- G.G., G.K., H.N.; Son Onay ve Sorumluluk- D.M., G.K., Ö.Ö.A., P.Y., Z.M.T.A., B.K., A.Y.Ş., H.N., G.G.; Süpervizyon- G.G., G.K., H.N.

Çıkar Çatışması: Yazarlar çıkar çatışması beyan etmemişlerdir.

Finansal Destek: Yazarlar finansal destek beyan etmemişlerdir.

Ethics Committee Approval: This study was approved by the Ethics Committee of Istanbul University Faculty of Medicine.

Informed Consent: Written consent was obtained from the participants.

Peer Review: Externally peer-reviewed.

Author Contributions: Conception/Design of Study- G.G., G.K., H.N., D.M.; Data Acquisition- D.M., G.K., Ö.Ö.A., P.Y., Z.M.T.A., B.K., A.Y.Ş.; Data Analysis/Interpretation- Ö.Ö.A., G.K.; Drafting Manuscript- D.M., G.K., Ö.Ö.A., P.Y., Z.M.T.A., B.K., A.Y.Ş.; Critical Revision of Manuscript- G.G., G.K., H.N.; Final Approval and Accountability- D.M., G.K., Ö.Ö.A., P.Y., Z.M.T.A., B.K., A.Y.Ş., H.N., G.G.; Supervision- G.G., G.K., H.N.

Conflict of Interest: Authors declared no conflict of interest.

Financial Disclosure: Authors declared no financial support.

\section{KAYNAKLAR/REFERENCES}

1. Cenevre Sözleşmesi (1951). Erişim: https://www.unhcr.org/1951refugee-convention.html Son Erişim Tarihi: 23.07.2020

2. Global Trends Forced Displacement in 2019. UNHCR, UN Refugee Agency. Erişim: https://www.unhcr.org/5ee200e37.pdf. Son Erişim Tarihi: 22.07.2020

3. Hassoy H. Sığınmacılara illişki Genel Durum. In: Türk Tabipleri Birliği Merkez konseyi editor. Savaş, Göç ve Sağıı. Ankara: Türk Tabipleri Birliği Yayınları; 2016. p. 17-20.

4. UNHCR Türkiye İstatistikleri. Erişim: https://www.unhcr.org/tr/ unhcr-turkiye-istatistikleri. Son Erişim Tarihi: 22.07.2020

5. T.C İçişleri Bakanlığı Göç İdaresi Genel Müdürlüğü. İstatistikler. Güncel Veriler. Geçici Koruma. Erişim: https://www.goc.gov.tr/ gecici-koruma5638. Son Erişim Tarihi: 22.07.2020

6. Topçuoğlu RA. Hayat Değiştirmek için Yola Çıkanlar Yola Çıkınca Değişen Hayatlar: Bir Müracaatçı Grubu Olarak Göçmen Çocuklar. Toplum ve Sos Hizmet 2014;25(1):89-107.
7. IOM, \& UNICEF. IOM and UNICEF data brief: migration of children to Europe. 2015. Erişim: https://www.iom.int/sites/default/files/ press_release/file/IOM-UNICEF-Data-Brief-Refugee-and-MigrantCrisis-in-Europe-30.11.15.pdf. Son Erişim Tarihi: 24.07.2020

8. Çocuk Haklarına Dair Sözleşme. UNICEF Türkiye. 2004. Erişim: https://www.unicefturk.org/public/uploads/files/UNICEF_ CocukHaklarinaDairSozlesme.pdf. Son Erişim Tarihi: 25.07.2020

9. T.C. İçişleri Bakanlığı. 6458 sayılı Yabancılar ve Uluslararası Koruma Kanunu. Resmi Gazete. 2013. Erişim:https://www.resmigazete.gov. tr/eskiler/2013/04/20130411-2.htm. Son Erişim Tarihi: 25.07.2020

10. AFAD. Geçici Koruma Altındaki Yabancılara İlişkin Hizmetlerin Yürütülmesi Genelgesi. 2014. http://www.madde14.org/images/d/ df/AFADGenelge20144.pdf. Son Erişim Tarihi: 24.07.2020

11. Efe İ. Türk Basınında Suriyeli Sığınmacılar. İstanbul: Siyaset Ekonomi ve Toplum Araştırmaları Vakfi Yayınları, 2015.

12. Adıgüzel Y. Göç Sosyolojisi. 4th ed. Ankara: Nobel Akademik Yayıncılık; 2020.

13. Taş D, Tekkanat SS. Yerel Halk ve Suriyeli Sığınmacılar Arasında Bir Kent: Elazığ Örneği. Aksaray Üniversitesi İktisadi ve İdari Bilimler Fakültesi Dergisi 2018;10(4):77-90.

14. Ager A, Strang A. Understanding integration: A conceptual framework. J Refug Stud 2008;21(2):166-91.

15. AFAD. Suriye'den Türkiye'ye Nüfus Hareketleri Kardeş Topraklarındaki Misafirlik. 2014.

16. Koç M, Görücü I, Akbıyık N. Suriyeli Sığınmacılar ve İstihdam Problemleri. Birey ve Toplum Sosyal Bilimler Dergisi 2015;5(9):6393.

17. Veul I. An exploration on why and how Syrian refugees settle down in Diyarbakır city. Wageningen University and Research; 2015.

18. Alptekin K, Ulutaş DA, Gündüz DU. Konya'da Geçici Koruma Altında Yaşayan Suriyeliler Üzerine Bir Çalışma. Sosyal Politika Çalışmaları Dergisi 2018;40(2):87-114.

19. Türkay M. Çocukların Sorunları. In: Türk Tabipleri Birliği Merkez Konseyi editor. Savaş, Göç ve Sağlık. Ankara: Türk Tabipleri Birliği Yayınları; 2016. p. 71-5.

20. UNHCR. Mülteci Çocukların Korunması Orta Doğu Ve Kuzey Afrika'da.

21. İlgazi A. Suriyeli Sığınmacıların Emek Piyasasına Etkileri. Gaziantep ve Şanlıurfa Örneği. Econharran Harran Üniversitesi IiBF Dergisi 2019;3(4):94-123.

22. Yıldırımalp S, İslamoğlu E, İyem C. Suriyeli Sığınmacıların Toplumsal Kabul ve Uyum Sürecine Illişkin Bir Araştırma. Bilgi Sosyal Bilimler Dergisi 2017;35:107-126.

23. Sarvan, S ,Efe, E . Mülteci Çcouklar ve Sorunları.Balıkesir Sağlık Bilimleri Dergisi 2020;9:55-62.

24. OECD. Making Integration Work. Refugees and others in need of protection. 2016.

25. Çakır H. Suriyeli Mülteci Kadınların Sosyo-Kültürel Değişime Uyum Çabaları: Yozgat Örneği. ÇOMÜ Uluslararası Sosyal Bilimler Dergisi 2017;2(4):53-68.

26. Karasu MA. Şanlıurfa'da Yaşayan Suriyeli Sığınmacıların Kentle Uyum Sorunu. Süleyman Demirel Üniversitesi İktisadi ve İdari Bilimler Fakültesi Dergisi 2016;21(3):995-1014.

27. Duğan Ö, Gürbüz S. Suriyeli Sığınmacıların Sosyal Entegrasyonuna Yönelik Bir Araşttrma. Turkish Studies Social Sciences 2018;13(26):529-546.

28. UNICEF. Turkey 2018 Humanitarian Results. 2018. 
29. UNICEF. Turkey Humanitarian Situation Report. 2019.

30. Uzun EM, Bütün E. Okul Öncesi Eğitim Kurumlarındaki Suriyeli Sığınmacı Çocukların Karşılaşttkları Sorunlar Hakkında Öğretmen Görüşleri 2016;1(1):72-83.

31. Yapıcı S. Suriyeli Öğretmen ve Veli Görüşlerine Göre Geçici Eğitim Merkezlerinin Değerlendirilmesi: Nitel Bir Araştırma. Yüksek Lisans Tezi. Marmara Üniversitesi İstanbul Sabahattin Zaim Üniversitesi. 2019 (Erişim 10/11/2020) https://openaccess.izu. edu.tr/xmlui/bitstream/handle/20.500.12436/329/Suat\%20Yap\% c4\%b1c\%c4\%b1.pdf?sequence=1\&isAllowed=y

32. Kaya A. Suriyeli Mülteci Çocukların Eğitimi Üzerine Bir Araştırma: Geçici Eğitim Merkezleri ve Müfredatları. Yüksek Lisans Tezi. Marmara Üniversitesi. 2019. (Erişim 10/11/2020) https://katalog. marmara.edu.tr/veriler/yordambt/cokluortam/BD9D7163E2CF-0D44-80A0-AB7A8AE2CD14/CF2F7C63-85E2-0447-8C07B141A6FEE28B.pdf

33. Uluocak GP. İ̧ Göç Yaşamış Ve Yaşamamış Çocukların Okulda Uyumu. Dokuz Eylül Üniversitesi Buca Eğitim Fakültesi Derg 2009;26:35-44.

34. T.C. Aile Çalışma ve Sosyal Hizmetler Bakanlığı. Şartlı Eğitim ve Şartlı Sağlık Yardımı.

35. UNICEF. UNICEF ve Avrupa Birliği, Şartlı Eğitim Yardımı (Ş.E.Y.) Programının Suriyeli ve Diğer Mülteci Çocukları Kapsayacak Şekilde Yaygınlaştırılmasını Duyurusu. 2020.
36. Polat S, Evliyaoğlu N. Göçmen çocuklar. Türkiye Klin J Pediatr Sci 2008;4(6):52-5.

37. Aydın D, Şahin N, Akay B. Göç olayının çocuk sağlığı üzerine etkileri. İzmir Dr Behçet Uz Çocuk Hast Derg 2017;7(1):8-14.

38. Türkiye Milli Pediatri Derneği. Çocuk ve Ergen Perspektifi ile Mülteci Akıl ve Ruh Sağlığı Çalıştayı Raporu. 2017.

39. Gültaç A, Yalçın Balçık P. Suriyeli Sığınmacılara Yönelik Sağlık Politikaları. Sak Med J 2018;8(2):193-204.

40. Geçici Koruma Altına Alınanlara Verilecek Sağlık Hizmetlerine Dair Esaslar. Yönerge No: 2875. 2015.

41. T.C. Sağlık Bakanlığı Türkiye Halk Sağlığı Kurumu. Faaliyet Raporu. 2016. Erişim: https://dosyasb.saglik.gov.tr/Eklenti/7585,raporpdf. pdf?0. Son Erişim Tarihi: 25.07.2020

42. Esin NM, Ardıç A, Nar Ş, Yıldırım B, Sunal N. İstanbul'un Bir Bölgesinde Yaşayan Suriyeli Göçmenlerin Yaşam Koşulları. 17. Ulusal Halk Sağlığı Kongresi Edirne; 2014.

43. Yetiz P. Batman İlinde 2013 Yili Kızamık vakaları. 16. Ulusal Halk Sağlığı Kongresi, Antalya; 2013.

44. Özmert EN, Derman O, Bideci A, Okumuş N, Boduroğlu K, Bakkaloğlu S, et al. Syrian children in Turkey: A model of action for national pediatric societies. Pediatrics 2019;143(2).

45. Kara F, Akgün N. Konya'ya Yerleşen Suriyeli Mültecilerin Sağlık Hizmetlerinden Yararlanmalarının Önündeki Engeller. 18. Ulusal Halk Sağlığı Kongresi, Konya; 2015. 